\title{
JACOPO GARZONIO
}

\section{Some considerations on the syntax of expletive subjects in Old Venetan and the emergence of subject clitics}

\begin{abstract}
Old Venetan varieties display different forms of third person subject pronouns. In particular, the reduced monosyllabic and asyllabic forms are strongly related to the expletive subject function. Even if the reduced forms do not have the same distribution of subject clitics in Modern Venetan, it can be argued that these forms have become clitics before the other pronouns. The article takes into consideration the syntax of expletive subjects in Old Venetan in relation to the rise of subject clitics in these varieties.
\end{abstract}

KEYWORDS: Subject Clitics, Expletive Subject, Old Venetan, Old Romance, Null Subject.

\section{Introduction*}

In this article I discuss the (morpho)syntactic properties of expletive subject pronouns in Old Venetan varieties, and more precisely in Old Venetian, Old Paduan and Old Veronese between the end of the $13^{\text {th }}$ and the end of the $14^{\text {th }}$ centuries. These medieval North Eastern Italo-Romance varieties do not present fully-fledged subject clitics, but third person pronouns display an alternation between a strong disyllabic and a reduced monosyllabic or asyllabic form. While it is true that the reduced form does not have the same syntactic properties of modern subject clitics, it nonetheless displays a peculiar syntax and is strongly associated with the expletive subject function. For this reason, I take into exam the behavior of expletive subjects in these varieties and consider it in relation to the emergence of subject clitics in the following stages of the history of Venetan.

* I wish to thank Silvia Rossi and three anonymous reviewers for the comments on a preliminary version of this article. 


\section{On the development of subject clitics in Venetan}

In her work on the relation between the richness of verbal morphology and the distribution of null subjects in the history of Venetan dialects, Poletto (2006) has proposed the following explanation of the development of subject clitics in these varieties (and, more in general, in Central Romance). Old Venetan, as discussed by Benincà (1984) and subsequent work, was a Verb Second language like Old French. According to this line of research, in Old Venetan the inflected verb occupies a C position in main clauses, preceding the standard subject position. This configuration is found in cases like (1), where the inflected verb has moved across the pronominal subject and the preverbal position is occupied by the pragmatically marked direct object, as represented in (2).

(1)

$$
\text { ...questo }
$$

this 'I will get this...' avrò- $\quad$ e... will-have I
(Lio Mazor, 14r, 7)

(2) $\quad[\mathrm{CP}$ questo $[\mathrm{C}$ avrò $[\mathrm{TP} e[\mathrm{~T}$ à̀ $]]]]$

This type of configuration is excluded in embedded clauses, where normally the subject is found in preverbal position. The Verb Second syntax of Old French, Old Venetan and many other medieval Romance varieties has been linked to the distribution of null subjects (cf. among many others Foulet 1958, Benincà 1984, Adams 1987, Roberts 1993). These languages do not display systematic pro-drop, as there are cases where an overt subject is missing and other cases where an overt pronominal subject is realized in contexts where it is excluded in standard pro-drop languages. The analysis developed by Benincà (1984) is based on the observation that the contexts where prodrop is possible are the same where the subject can appear in postverbal position, i.e. in main clauses. This asymmetry, observable in examples like those in (3) for Old Venetian, is the reason why this system is labeled 'Asymmetric pro-drop' in the literature. In (3a) the subject is null, while in (3b) the subject of the embedded clause $e l$ is overt even if it is coreferential with the main clause subject.

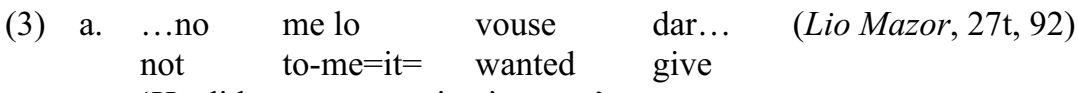

'He did not want to give it to me'

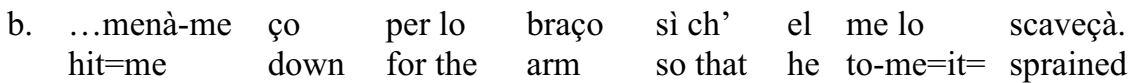
'...he stroke me on the arm so that he sprained it.' (Lio Mazor, 3t, 48)

Adams (1987) has analyzed this pattern assuming that for the licensing of null subjects the overt agreement morphology on the inflected verb is not sufficient. According to her, a null subject is possible only if it is governed by the inflected verb (i.e. by the head carrying the agreement features), a configuration realized when the 
verb is moved to the CP layer. Following this line of research, Poletto (2006) has observed the development of the null subject system in the history of Venetan varieties (mainly Venetian and Paduan). In the Renaissance period, when the Verb Second syntax is gradually lost, these varieties maintain an asymmetric pro-drop system, but the pattern is different. There are three persons, i.e. first singular and plural, and second plural, that allow null subjects in all contexts, as can be observed in (4)(Poletto's 2006 examples (13)):

(4) a. pro Ve suplico...

(I) you=pray

'I pray you...'
(Calmo 7215)

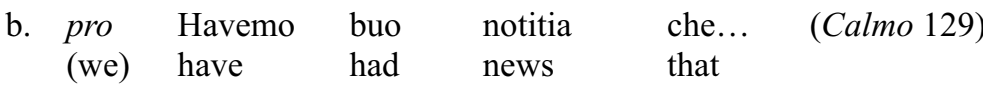

'We heard that...'

$\begin{array}{llllll}\text { c. } & \text { pro } & \text { Dirè } & \text { a } & \text { Ser Zuan } & \text { che... } \\ \text { (you) } & \text { will-say } & \text { to } & \text { Sir Z. } & \text { that } & \end{array}$

'You will tell Sir Z. that...'

The other three persons can have no overt subject pronouns only if the $\mathrm{CP}$ contains an item carrying a [+wh] feature, like interrogative phrases or the conditional complementizer. In other configurations, the subject pronoun must be present. In (5) I provide a minimal pair (Poletto's 2006 examples 16b and 17a): in (5a) the third person subject pronoun is null and the CP hosts the temporal wh introducer quando 'when', while in (5b) the subject pronoun is present and the CP layer is empty.
a. $\quad$...com
fa l'orsa quando
pro
(she)
se guz $\begin{array}{lll}\text { as does the bear when (she) } & \text { REFL=sharpens } \\ \text { '... as the bear does when it sharpens its claws' } & \text { (Ruz. 105) }\end{array}$
gi ongi
b. El m'ha lagò le cavale... (Ruz. 78) he to-me=has left the horses
'He left me the horses...'

Under this account, the licensing of null subjects has changed in the Renaissance period: if the $\mathrm{C}$ position does not host a specific item governing the subject position, a subject pro is licensed only if the verb morphology is able to fully identify the phifeatures of the subject. This last condition is true for the first singular and plural, and the second plural, while in the other cases the verb morphology can be ambiguous, since Venetan varieties do not distinguish number in the third persons and the second singular is identical to the third person in some high frequency irregular verbs (e.g. Paduan te ga 'you have', el ga 'he has', i ga 'they have'). In more formal terms, Poletto (2006: 184) formulates the following conditions and definitions for the licensing of null subjects: 
I. C is a pro-drop licenser iff it is strong.

II. The inflected verb in T is a pro-drop licenser iff it is strong.

III. C is strong when it contains a feature different from the unmarked one.

IV. Agreement in T is strong when it contains a morphologically realized + person and + number feature.

Interestingly, present day Venetan varieties, like Modern Venetian or Modern Paduan, have developed subject clitics only for the second singular and third singular and plural persons, i.e. the persons requiring an overt pronoun in the Renaissance period. On the basis of this observation, Poletto (2006) proposes that the development of an incomplete paradigm of subject clitics is in fact a consequence of the asymmetric pro-drop configuration. In other words, only the obligatory subject pronouns of the second singular, and the third singular and plural persons have changed into syntactic heads, presumably following the Head Preference Principle (van Gelderen 2011) ${ }^{1}$. In this way, Poletto conciliates a proposal originally formulated by Haiman (1974), i.e. that there is a link between the development of subject clitics and the loss of the medieval Verb Second system, with the incomplete paradigm of subject clitics in ItaloRomance varieties.

\section{Expletive subjects in Old Venetan}

The account proposed by Poletto (2006) is based on the development of null subjects and subject clitics in the domain of argumental/referential subjects. However, there are some reasons to assume that adding expletive subjects to the picture makes this type of analysis not completely sufficient. In general, it is known that, in the distribution of pro-drop, expletive subjects can behave differently from referential subjects. For instance, while Southern and Western Slavic languages can be considered fully pro-drop languages, in Eastern Slavic languages (with the exception of some

1. "A possible explanation for this change has to do with a 'regularization' of the asymmetric system: in the Renaissance period French, Venetian, and Paduan could have null subjects across the whole paradigm, even though the licensing conditions of a null subject was different according to person. The loss of null subject licensing through government by strong $\mathrm{C}^{\circ}$ should have given rise to a real asymmetric system, where only some persons (i.e. those that admitted licensing by a strong $\mathrm{I}^{\circ}$ ) could have a null subject. Probably the fact that subject pronouns became clitic heads has to do with this asymmetry: becoming heads, subject clitics created a new type of null subject licensing (and identifying) performed by a head which is not $\mathrm{T}^{\circ} / \mathrm{AgrS}^{\circ}$, but a higher one. In other words, the null subject licensing (and identifying) process by the clitic head is similar to the one performed by $\mathrm{C}^{\circ}$, because the head is higher than $\mathrm{T}^{\circ} / \mathrm{AgrS}^{\circ}$, but, by contrast with licensing by $\mathrm{C}^{\circ}$, the subject clitic can also identify referential null subjects, and this is probably done in a spec-head agreement configuration." (Poletto 2006: 185) 
Russian dialects) expletive subjects are obligatorily null, while referential subjects are normally overt, even if they can be elided in some discourse configurations. For this reason, Franks (1995) proposed two separate parameters, a null referential subject parameter and a null expletive subject parameter. Moreover, there is interlinguistic variation regarding the type of expletive subjects that can be null. A good example is provided by the Germanic family: in languages like Icelandic or Yiddish both impersonal and meteorological subjects are null, while in languages like German or Dutch impersonal subjects are null, but meteorological subjects are obligatorily realized (e.g. in German Gestern wurde (*es) getanzt 'Yesterday there was dancing' and *(Es) regnet 'It rains'); cf. Biberauer (2010) for a discussion of this variation in a parametric account ${ }^{2}$.

In the case of Old Venetan varieties, expletive subjects display some peculiar morpho-syntactic properties, which I illustrate in this section. In general, from the point of view of the paradigm, there is an interesting asymmetry regarding the third persons in comparison with all the other persons. In (6) I illustrate the paradigm of personal pronouns observable in the Old Paduan ( $13^{\text {th }}$ and $14^{\text {th }}$ centuries) legal and practical texts edited by Tomasin (2004)

(6) first singular: mi, eo, e', io, hio, yo

second singular: $t u$

third singular: ello, elo, el, l-, luy / ela, lla, la

first plural: nui, nuy, nue, $n u, n o$ '

second plural: vuy

third plural: igi, $i, y$, lor, loro / le

Leaving aside the problem of some orthographic variants and the fact that precisely at this stage the forms not derived from the nominative appear in some contexts, like in coordination, there is a clear asymmetry between the third persons and the rest of the paradigm: only the third persons have both a disyllabic form (el(l)o 'he', ela 'she', $i g i$ 'they') and a monosyllabic or asyllabic form (elll' 'he' la 'she', $i$ 'they', see also Pescarini 2012). While in the case of referential subjects it is not clear if there is a syntactic factor regulating the variation, and in many texts it seems to depend on the phonological context, in the case of expletive subjects the picture is clearer. As Garzonio, Rodeghiero and Rossi (2018) show, in a group of Old Paduan and Old Veronese texts referential subjects can present both the disyllabic and the "reduced" mono-/asyllabic form, but expletive subjects can only present the latter. In the Old Venetian texts that they have taken into consideration the difference is not so systematic, but there is a clear tendency in the same direction. More precisely, the Zibaldone da Canal has a conservative system where both ello and $e l$ can be referential

2. Cf. Brandner (1993: 83-84) on the difference between cases like Gestern wurde (*es) getanzt and ...weil es sich hier gut tanzt 'because one can dance well here', where the overt expletive is necessary to bind the anaphoric pronoun. 
and expletive, but $e l$ is normally found after the complementizer. However, in the Tristano Veneto ello is referential and $e l$ is expletive in circa $90 \%$ of cases. I refer to Garzonio, Rodeghiero and Rossi (2018) for the statistical details. Furthermore, Ragucci (2020) has noticed that in another Old Venetian text, the Navigatio Sancti Brendani, $e l$ is only used for the expletive. It is important to point out that the reduced pronominal forms of Old Venetan do not have the same syntactic distribution of modern subject clitics. The examples in (7) show that $e l$ (in these cases used as expletive), like its disyllabic counterpart ello, always precedes the preverbal negation marker, while in Modern Venetan the corresponding subject clitic follows it (also displaying univerbation $n o l)$ :

(7) a. ...ch'el no è più ora né staxon de dormir. (Planctus 29) that it not is anymore hour nor season of sleep '... since it is not time to sleep anymore.'
b. el no roman in la radixe it not remains in the root 'In the root no benefit remains.'
alguno çoamento. (Serapiom 270) any benefit

Furthermore, while modern subject clitics are normally repeated in coordinated predicates, the reduced forms of Old Venetan are normally absent in the second conjunct, like in (8a) (with some exceptions in the case of the "paraipotassi" construction, like in (8b)).

(8) a. E quando fo vespro, el se partì e andè in Betania and when was evening he REFL=left and went to B.

'When it was evening, he left and went to Bethany.' (Passione Veronese 15)

b. E cum'el levà dela oration ed el veno ai discipuli soi. and when he raised from-the prayer and he came to-the disciples his 'After he finished his prayer, he came to his disciples'

(Planctus 39)

Given this distribution, it is possible to assume that items like el were weak pronouns at this stage (in the sense of Cardinaletti and Starke 1999).

Besides the different distribution of the full and the weak forms, expletive and referential subjects have another relevant difference. As I have briefly illustrated in the previous section, in Old Venetan referential subjects can be null in main clauses, but usually are overt in embedded clauses. On the other hand, the expletives are often overt also in main clauses, which is unexpected since overt subjects appearing in contexts where they are optional are usually motivated by discourse and informational factors. In (9) I provide some examples from respectively an Old Venetian, an Old Paduan and an Old Veronese text:

(9) a. Ello sì à mestier ch'io lo vada a çerchar. (Zibaldone da Canal)
it so has necessity that I him=go to search
'It is necessary that I go to search for him.' 
b. El se tria le foie co(n) tuto lo arbore... (Serapiom 7)
it $\quad \mathrm{REFL}=$ cuts the leafs with all the tree
'One cuts the leaves with the whole tree...'
c. E l'era noto... (Passione Veronese 32)
and it was night
'It was night...'

In cases like (9a-b) the expletive subject, a full form in the first case and a weak one in the second, is in sentence initial position, while in (9c) the asyllabic form is in second position. The first two cases clearly show that ello/el is not in the standard subject position, as it should be postverbal in such a case. Additionally, the example (9a) shows that ello precedes si, which is a focus marker located in the left periphery. More in general, in the texts examined by Garzonio, Rodeghiero and Rossi (2018) there are no cases of postverbal expletive subjects. In (10) I provide a minimal pair: in the first example the first position hosts the direct object DP (with a relative clause that I do not report here), but the expletive subject is nevertheless preverbal, while in the second example the first position is occupied by tuta fiada and the referential subject is postverbal as expected. It should be pointed out that cases of postverbal referential pronouns are not common precisely because it is the configuration allowing null subjects.

(10) a. tuto questo [...] el ve convien sufrir.

all this it to-you=befits suffer

'It is necessary that you bear all this.'

(Tristano Veneto 317)

b. ...ma tuta fiada farave ello volontiera pecior languir per ella aver but nevertheless would-do he gladly worse suffering for her get

'He would gladly suffer more to get her' (Tristano Veneto 95)

Summarizing, there are two facts that single out expletive subjects in Old Venetan texts: only the reduced/weak forms can be expletives (except in some of the older Venetian texts), and they do not follow the same distribution of referential pronouns with respect to the null subject licensing. In the next section I propose an account of the syntax of expletives in Old Venetan and discuss some of its consequences for an explanation of the emergence of subject clitics.

\section{Analysis}

In some languages the different types of expletive subjects behave differently with respect to the pro-drop property (cf. Biberaurer 2010 among others). However, in Old Venetan there is not a correlation between the type of expletive and its overt realization. In (11) I provide some examples showing that all types of expletives can be overt: 
(11) a. E s'ello ploverà... (Zibaldone da Canal) Meteorological predicate and if it will-rain

'And if it will rain...'

b. E l'era persone che... (Planctus 105) Existential predicate and it was people that

'There were people that...'

c. E subitamente el vene un vento... (Bibbia Istoriata, Ex. 57) Postverbal subject and suddenly it came a wind

'Suddenly the wind rised...'

d. El me parea vedere... (Bibbia Istoriata, Gen. 245) Raising verb

it to-me=seemed see

'It seemed to me to see...'

e. L'è vero che... (Bibbia Istoriata, Num. 60) Subject clause it is true that

'It is true that...'

Considering that all types of expletive subjects can be overt and that their realization appears to be optional, it is possible to hypothesize that the presence of these pronouns is not related to the pro-drop parameter at this stage. As discussed by Cognola and Casalicchio (2018), besides true expletive subjects, which are obligatory in all contexts, there are semi-expletives or discourse expletives, which are used only in some specific contexts. A good example of an item of this type is the Neapolitan pronoun chello (Sornicola 1996; Ledgeway 2009), which cannot be used in neutral contexts, but only in adversative, exclamative and other pragmatically marked environments:

(12) a. Chello chiove!

it rains

'It is raining!' (e.g. as answer to a question like 'Aren't you going out?')

$\begin{array}{lllll}\text { b. Chello nun se pò } & \text { ascì } & \text { a sera! } \\ \text { it } & \text { not } & \text { REFL=can } & \text { go-out the evening }\end{array}$

'It is impossible to go out in the evening!'

However, in the case of the Old Venetan texts, the high frequency of overt expletives suggests that their presence is not pragmatically driven. A tentative explanation is that, while in embedded clauses the expletive is present because a null subject is not licensed since the verb is not in $\mathrm{C}$, in main clauses the expletive has the role of a dummy first position item, satisfying an edge/EPP feature of the $\mathrm{C}$ head (on this see also Singh 2021, who has examined a different version of the Navigatio). A confirmation of this hypothesis is provided by the following observation. In general, expletives with presentative postverbal subjects are very common in Old Venetan main clauses. However, very often the expletive is absent if the first position is occupied by a locative adverb or phrase, as the minimal pair in (13) shows: 
(13) a. Elo li vene [...] incontra uno belo vetran... (Navigatio 90) it to-them=came towards a nice old-man 'A nice old man came towards them...'

b. Qua vene lo procurador... (Navigatio 66) here came the procurator 'There arrived the procurator...'

In (13b) the first position is occupied by the locative adverb qua and there is no expletive with the postverbal subject, while in (13a) the first position is occupied by the expletive elo. The alternation can be represented as in (14):

$$
[\mathrm{CP} \text { elo/qua }[\mathrm{C} \text { vene }[\mathrm{TP} \text { pro }[\mathrm{T} \text { e }[\mathrm{vP}]]]]]
$$

The analysis can be refined assuming a split CP theory. In Old Venetian texts where the disyllabic form el(l)o can be used as expletive, this always precedes the focus marker sì, like in (9a), reproduced here as (15):

$$
\begin{aligned}
& \text { Ello sì à mestier ch'io lo vada a çerchar. (Zibaldone da Canal) } \\
& \text { it so has necessity that I him=go to search } \\
& \text { 'It is necessary that I go to search for him.' }
\end{aligned}
$$

This order suggests that ello occupies the specifier of a projection higher than FocusP. Assuming an approach that distinguishes Verb Second languages according to the projection reached by the inflected verb (cf. Wolfe 2018 among others), I assume that in cases like (15), where the verb movement to the higher left periphery is blocked by the focus feature, the expletive occupies the specifier of the projection normally involved in the Verb Second construction, very likely ForceP:

\section{(16) [Force P Ello [FocusP sì [Focus à [Fin ̀̀ [TP pro [T ̀̀ [vP ]]]]]]]}

The weak form $e l$, however, very rarely precedes sì, and in all the 8 occurrences of the sequence $e l$ sì in Old Venetan texts of the database of the Opera del Vocabolario Italiano, the pronoun is referential. The different behavior of ello and el across the Old Venetan domain could be evidence that the system is undergoing a change between the $13^{\text {th }}$ and the $14^{\text {th }}$ centuries (with Old Venetian being slightly more conservative than Old Paduan and Old Veronese). More precisely, it seems that $e l$ is reinterpreted as the lexicalization of a strong agreement feature on the verb. It is not clear if this process is related to a change in the Verb Second syntax, but it is important to point out that it involves the third singular, which is not distinguished from the third plural by verb morphology. In more formal terms, I propose that the weakening of the expletive pronoun consists in a downward reanalysis of the dummy first position expletive, so that it is merged in the specifier of the inflected verb moved to $\mathrm{C}$, to which it transfers its phi-features through spec-head agreement. 
If this proposal is on the right track, one could ask if in Venetan varieties expletive pronouns have become clitic elements before the other subject pronouns. As I have discussed in section 3, the distribution of $e l$ in Old Venetan suggests that it is not yet a clitic comparable to modern subject clitics. However, in the Renaissance period, when Verb Second is lost and the licensing of null subjects is based on the factors discussed in section 2, the distribution of expletive pronouns is different from that of referential ones described by Poletto (2006). For instance, in Calmo's letters it is possible to find cases where expletive $e l$ surfaces in embedded clauses even if C is strong in Poletto's terms:

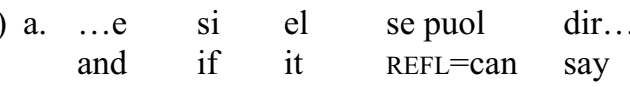

$$
\begin{aligned}
& \text { '...if it is possible to say...' } \\
& \text { b. ...quando el piove... } \\
& \text { when it rains } \\
& \text { '...when it rains...' }
\end{aligned}
$$

(Calmo, 2, 29)

In other words, in these cases $e l$ is present even if $\mathrm{C}$ could license a null subject. There are two possible explanations for this pattern. A first possibility is that $e l$ is not a weak pronoun but already a subject clitic. Cases of third person subject clitics that precede negation and are optional in coordination are uncommon, but not unattested. Ragucci (2020) has shown that for some speakers of Western Trentino varieties, the so-called "semi-ladine" varieties of the Val di Non and the Val di Sole, the masculine third singular subject clitic can precede negation and is optional in coordination ${ }^{3}$ :

(18) a. El canta e bala tutte le sere.
he $=$ sings and dances all the evenings
'He sings and dances every night.'

$\begin{array}{llll}\text { b. El no magna frutta. } & \\ \text { he not eats } & \text { fruits } \\ \text { 'He does not eat fruits.' } & \end{array}$

It is interesting that these varieties have subject clitics only for the third persons, a paradigm different from that of modern Venetan varieties ${ }^{4}$.

3. It should be pointed out that the clitic nature of $e l$ in these varieties is confirmed by the other canonical tests for subject clitics, like for instance the obligatory doubling of preverbal subject DPs (El popo el magna 'l pom 'The boy eats the apple').

4. Notice that I am not claiming that the presence of third person verbs with no distinction for number is a sufficient or necessary property in order to have partial pro-drop (third persons vs. the rest of the paradigm), since there can be other factors regulating the type of pro-drop. 
A second possibility is that the licensing of null subjects in Old and Renaissance Venetan is not determined by strong features on $\mathrm{C}$, but by the type of null topics that can be hosted in the left periphery of a clause and the way the features of these topics can identify the subject (cf. Cognola and Walkden 2019 for an analysis in these terms of Old Italian and Old High German). The fact that expletive subjects must be overt could be considered evidence that they cannot be licensed at all since there are not expletive topics with which they could agree. Further research (in particular quantitative analysis of the Renaissance texts) will be needed in order to determine which possibility is to be preferred in this case.

\section{Concluding remarks}

In this article I have shown that in Old Venetan expletive subject pronouns have some specific properties from the point of view of both morphology and syntax. In particular, in main clauses expletive subject pronouns are located higher than the standard subject position in the specifier of T(ense). This explains why they do not display the asymmetric pro-drop pattern of referential pronouns. This, in turn, has some consequences for the analysis of the licensing of pro-drop in general and the relation between overt subject pronouns and the emergence of subject clitics in the history of Venetan varieties.

\section{Bibliographical references}

Adams, M. 1987, From Old French to the theory of pro-drop, «Natural Language and Linguistic Theory» 5: 1-32.

Benincà, P. 1984, Un'ipotesi sulla sintassi delle lingue romanze medievali, «Quaderni Patavini di Linguistica» 4: 3-19.

Biberauer, Th. 2010, Semi null-subject languages, expletives and expletive pro reconsidered, in T. Biberauer et al. (eds.), Parametric Variation: Null Subjects in Minimalist Theory, Cambridge, Cambridge University Press: 153-199.

Brandner, E. 1993, The projection of categories and the nature of agreement, in G. Fanselow (ed.), The Parametrization of Universal Grammar, Amsterdam, Benjamins: 73-122.

Cardinaletti, A. - Michal S. 1999, The typology of structural deficiency. A case study of the three classes of pronouns, in $\mathrm{H}$. van Riemsdijk (ed.), Clitics in the Languages of Europe, Berlin/New York, Mouton de Gruyter: 145-233.

However, if subject clitics derive from mandatory subject pronouns, it is necessary to assume that at some point Venetan was an obligatory expletive subject language. 
Cognola, F. - Casalicchio, J. 2018, On the null-subject phenomenon: An example of successful linguistic research, in F. Cognola - J. Casalicchio (eds.), Null Subjects in Generative Grammar: A Synchronic and Diachronic Perspective, Oxford, Oxford University Press: 1-28.

Cognola, F. - Walkden, G. 2019, Pro-drop in interrogatives and declaratives: A parallel study of Old High German and Old Italian, «Linguistik Online» 100: 95-140.

Foulet, L. 1958, Petite syntaxe de l'ancien français, Paris, Honoré Champion.

Franks, S. 1995, Parameters of Slavic Morphosyntax. Oxford, Oxford University Press. Garzonio, J. - Rodeghiero, S. - Rossi, S. 2018, I pronomi soggetto espletivi nelle varietà venete medievali, in A. Chilà - A. De Angelis (eds.), Capitoli di morfosintassi delle varietà romanze d'Italia: teoria e dati empirici, Palermo, Centro di Studi filologici e linguistici siciliani: 201-219.

van Gelderen, E. 2011, The Linguistic Cycle: Language Change and the Language Faculty, Oxford, Oxford University Press.

Haiman, J. 1974, Targets and syntactic change, The Hague, Mouton.

Ledgeway, A. 2009, Grammatica diacronica del napoletano, Tübingen, Niemeyer.

Pescarini, D. 2012, Esiti di ILLUM in Veronese antico, in P. Bianchi - N. De Blasi, C. De Caprio - F. Montuori (edd.), La variazione nell'italiano e nella sua storia. Varietà e varianti linguistiche e testuali, Firenze, Franco Cesati Editore: 359367.

Poletto, C. 2006, Asymmetrical Pro-Drop in Northern Italian Dialects, in P. Ackema (ed.), Arguments and Agreement, Oxford/New York, Oxford University Press: 159-194.

Ragucci, E. 2020, Dalla Navigatio Sancti Brendani alle varietà moderne: la questione dei pronomi di terza persona, MA thesis, University of Padua.

Roberts, I. 1993, Verbs and Diachronic Syntax: A Comparative History of English and French, Dordrecht, Kluwer.

Singh, O. 2021, Verb second in Old Venetian, «Isogloss» 7: 1-28.

Sornicola, R. 1996, Alcune strutture con pronome espletivo nei dialetti italiani meridionali, in P. Benincà et al. (eds.), Italiano e dialetti nel tempo: saggi di grammatica in onore di G. Lepschy, Roma, Bulzoni: 323-340.

Tomasin, L. 2004, Testi padovani del Trecento. Edizione e commento linguistico, Padova, Esedra.

Vanelli, L. 1987, I pronomi soggetto nei dialetti settentrionali dal Medio Evo a oggi, «Medioevo Romanzo» 12: 173-211.

Wolfe, S. 2018, Verb Second in Medieval Romance, Oxford, Oxford University Press. 